\title{
FRA ANGELICO'S “ANNUNCIATION” AT SAN MARCO
}

Imagine: an angel whose wings imply The colors of the world. No wonder Mary's head inclines, not wanting To miss a word, her book half-dropped From her hand in her surprise At such a visitor.

If angels had not traditionally been Thought of as male, one might mistake These two for sisters: their plaster robes Stained from the same palette of pink, Their hair swept off their faces, falling In similar curls.

But they keep their distance, as does Dominic, The saint behind the pillar in the yard, Who from the Renaissance looks on shyly, His hands held formally in prayer, His black and white habit austere Next to the angel's wings, the venial Pink lingering, not yet redeemed, In Mary's cheek.

The monk whose cell this painting lit Would take Brother Dominic's posture As a model for his own when contemplating This event, which looms with penitents And spires. And probably, a prayerful stance Is appropriate; how often, after all, Are we promised saviors?

Still, it may have been more instructive If the saint had been braver, And reached out to finger those wingsJust inches away-and let us know what An angel's made of. 